\title{
Infection, cure and egg reduction rates of soil-transmitted helminth infections after anthelminthic drugs treatment among school children in Kokap, Yogyakarta, Indonesia
}

\author{
Fitria Siwi Nur Rochmah ${ }^{1,2}$, E. Elsa Herdiana Murhandarwati ${ }^{3}$, Sri Sumarni ${ }^{3}$ \\ ${ }^{1}$ Master Program in Basic Medical Science and Biomedical Science, Faculty of Medicine, \\ Universitas Gadjah Mada, ${ }^{2}$ Department Parasitology, Faculty of Medicine, Universitas \\ Islam Indonesia, ${ }^{3}$ Department Parasitology, Faculty of Medicine, Universitas Gadjah Mada, \\ Yogyakarta, Indonesia
}

DOI: http://dx.doi.org/10.19106/JMedSci004804201605

\begin{abstract}
The prevalence of helminthiasis on primary school children in Indonesia is high, around 40$60 \%$. This study aims to assess the impact of treatment and predictors of soil-transmitted helminth (STH) infections at 3 months after treatment. Population of this study was students of a primary school in Kokap (Sekolah Dasar Negeri/SDN Gunung Agung), Kulon Progo, Yogyakarta, determined based on the inclusion and exclusion criteria $(n=65)$. Stool samples examined using Kato Katz method. Students infected with STH were given appropriate treatment and stool samples were collected again to determine cure rate (CR) and egg reduction rate (ERR) at 2 week post-treatment and at 3 months post-treatment to determine incidence of re-infection, new infection or failed treatment. Information on personal hygiene and sanitation were collected by interview with students of SDN Gunung Agung. Treatment with pyrantel pamoat was effective against hookworm and Ascaris lumbricoides with CR of $100 \%$ and ERR of $100 \%$ while treatment with albendazol was ineffective against Trichuris trichiura ( $C R=12.8 \%$, ERR $=62.4 \%$ ) though the Wilcoxon test for T. trichiura showed a significant reduction egg count (epg) before and 2 week after treatment $(p<0.05)$. The overall infection rate at 3 months after treatment was $35.4 \%$ with cases of re-infection, new infection and untreated cases. This result was not significantly different with infection rate before treatment $(p>0.05)$. The existence of double infection before treatment showed $p$ value $<0.05(O R=2)$ with the prevalence of STH infections 3 months after treatment. Bivariate analysis between personal hygiene and environmental sanitation with the prevalence of STH infections 3 months after treatment was obtained $p$ value $>0.05$. Presence of re-infection, new infection and untreated cases confirms that an integrated approach is necessary to control STH infection in Kokap, Kulon Progo, Yogyakarta.
\end{abstract}


Rochmah et al., Infection, cure and egg reduction rates of soil-transmitted helminth infections after anthelminthic drugs treatment among school children in Kokap, Yogyakarta, Indonesia

\section{ABSTRAK}

Angka kecacingan anak-anak sekolah dasar di Indonesia masih cukup tinggi berkisar antara 40 - 60\%. Penelitian ini bertujuan untuk mengevaluasi pengobatan yang diberikan dan mengetahui faktor yang berpengaruh terhadap infeksi soil-transmitted helminth (STH) 3 bulan paska pengobatan. Populasi pada penelitian ini adalah siswa Sekolah Dasar (SD) Negeri Gunung Agung, Kulonprogo, Yogyakarta yang dipilih berdasarkan kriteria inklusi dan ekslusi ( $n=65$ ). Sampel feses diperiksa menggunakan metode Kato Katz. Siswa yang mengalami infeksi STH kemudian diberikan pengobatan yang sesuai dan sampel fese diperiksa lagi untuk mengetahui cure rate (CR) dan egg reduction rate (ERR) pada 2 minggu setelah pengobatan dan 3 bulan paska pengobatan untuk mengetahui kejadian reinfeksi, infeksi baru maupun gagal pengobatan. Wawancara langsung dilakukan untuk mendapatkan informasi tentang higiene personal dan sanitasi lingkungan rumah. Pengobatan pirantel pamoat cukup efektif untuk mengobati infeksi hookworm dan $A$. lumbricoides dengan CR dan ERR sebesar 100\%, sedangkan albendazol kurang efektif untuk infeksi $T$. trichiura ( $C R=12,8 \%$ dan $E R R=62,4 \%)$. Walaupun demikian, penurunan rerata hitung telur T.trichiura sebelum pengobatan dan 2 minggu setelah pengobatan menunjukkan adanya perbedaan yang signifikan $(p<0,05)$. Prevalensi infeksi STH 3 bulan setelah pengobatan sebesar 35,4\% yang terdiri dari kasus reinfeksi, infeksi baru dan gagal pengobatan. Hasil ini tidak menunjukkan perbedaan yang bermakna dengan angka infeksi sebelum pengobatan $(p>0,005)$. Hubungan antara adanya infeksi ganda dengan prevalensi infeksi STH 3 bulan setelah pengobatan menunjukkan $p<0,05(O R=2)$. Analisis bivariat antara higiene perorangan dan sanitasi lingkungan dengan prevalensi infeksi STH 3 bulan setelah pengobatan didapatkan $p>0,05$. Adanya kasus reinfeksi, infeksi baru dan gagal pengobatan menunjukkan perlunya pendekatan yang terintegrasi dalam mengontrol infeksi STH di Kokap, Kulon Progo, Yogyakarta.

Keywords: soil-transmitted helminth - anthelminthics - cure rate - egg reduction rate reinfection

\section{INTRODUCTION}

Soil-transmitted helminth (STH) infections occur in many developing countries especially among communities in rural area. ${ }^{1}$ Despite many control programmes implemented by public and private sectors, the prevalence of STH infection is high in Indonesia. Prevalence of STH on primary school children in Indonesia is around $40-60 \%{ }^{2}$ Soil-transmitted helminth reinfection is closely related to the continuous exposure to the source of infection in the communities. Previous studies reported that STH reinfection occured as early as 2 months after deworming ${ }^{3,4}$ and STH reinfection rate was reported high due to the source of infection in the communities. ${ }^{5}$

Transmission of STH infection occurs through contact with the contaminated soil (hookworm) or the consumption of food contaminated with of infective eggs of helminths (A. lumbricoides dan T. trichiura) ${ }^{6}$ Another important factor that affect the transmission of STH according to Hoa et al. ${ }^{7}$ is indirect transmission through hands or nails contaminated with STH eggs, particularly for children that have soil contact during their play time.

The STH infections reported from a rural area in Kokap Sub District, Kulon Progo District, Yogyakarta in 2009 showed that the prevalence of helminthic infection was around $21 \%$ for the first grade students in 25 primary schools in Kokap I Primary Health Center. ${ }^{8}$ In 2011, the prevalence in 4 primary schools observed was ranged from 17-30\%. ${ }^{9}$ At the end of 2012, the highest prevalence of STH infection was reported from Gunung 
Agung Primary School i.e. around 29\%. Post-treatment evaluation for anthelminthic treatment following STH treatment program has not been studied at this Primary Health Center. This study aims to assess the impact of treatment and predictors of STH infection at 3 months after treatment.

\section{MATERIALS AND METHODS}

Population of this study was students of a primary school, Kokap, Kulonprogro (SDN Gunung Agung). Total sampling $(\mathrm{n}=65)$ was used in concordance with the Kokap I Primary Health Center programs. This research was carried out for 4 months at the end of May to September 2013. All students were required to collect a stool samples for being examined with Kato Katz method. ${ }^{10}$ Slides were examined under a light microscope (40-100 magnification) and the number of helminth eggs per gram of stool (epg) was recorded separately for each parasite.

Students infected with STH were given appropriate treatment and asked to collect stool samples again to determine the cure rate (CR) and egg reduction rate (ERR) at 2 weeks and at 3 months post-treatment to determine the incidence of reinfection, new infection or failed treatment. Single dose of pyrantel pamoate $(10 \mathrm{mg} / \mathrm{kg})$ was given for treatment for hookworm and A. lumbricoides infection, while single dose albendazole (400 $\mathrm{mg}$ ) for $T$. trichiura infection. ${ }^{11}$ The CR and ERR were calculated using the formulated below ${ }^{5}$ :

$$
\begin{gathered}
\mathrm{CR}=\frac{\begin{array}{c}
\% \text { prevalence before treatment }- \\
\% \text { prevalence after treatment }
\end{array}}{\text { \% prevalence before treatment }} \times 100 \\
\mathrm{ERR}=\frac{\begin{array}{c}
\text { mean epg before treatment- } \\
\text { mean epg after treatment }
\end{array}}{\text { mefore treatment }} \times 100
\end{gathered}
$$

This study was conducted with an approval by the Ethics Committee of Medicine and Health Research, Faculty of Medicine, Universitas Gadjah Mada, Yogyakarta.

\section{RESULTS}

TABLE 1 shows demographic characteristics of study subjects. Subject gender was equally balance, with age ranges from 7 to 13 years old. Parents' educational level was relatively low (illiterate to elementary level).

TABLE 1. Demographic characteristics of primary school students in Kokap, Kulon Progo, Yogyakarta

\begin{tabular}{lcc}
\hline \multicolumn{1}{c}{ Characteristis } & $\mathrm{n}$ & $\%$ \\
\hline Sex & & \\
Boys & 35 & 53.8 \\
Girs & 30 & 46.2 \\
Age (years) & & \\
7 & 5 & 7.4 \\
8 & 10 & 15.4 \\
9 & 21 & 32.3 \\
10 & 6 & 9.2 \\
11 & 7 & 10.8 \\
12 & 13 & 20.0 \\
13 & 3 & 4.6 \\
Parent's education & & \\
Graduate & 0 & 0 \\
Secondary schools & 12 & 18.5 \\
Elementary or illiterate & 53 & 81.5 \\
\hline Total & 65 & 100 \\
\hline
\end{tabular}

Twenty eight out of 65 participants (43.1\%) were identified having STH infections at pre-treatment interval. At 3 months after anthelminthic treatment, the prevalence of STH infection was $35.4 \%$. The STH infections were both single and mixed infections. The most dominant type was a single infection of $T$. trichiura (TABLE 2). The results of examination also indicated that 
Rochmah et al., Infection, cure and egg reduction rates of soil-transmitted helminth infections after anthelminthic drugs treatment among school children in Kokap, Yogyakarta, Indonesia

the intensity of STH infections was mostly relatively light infections. No significant difference was observed between the STH infection rate before and at 3 months after treatment $(\mathrm{p}>0.05)$ (TABLE 3$)$.

TABLE 2. Infection rate of STH at pre-treatment and 3 months post-treatment intervals at a primary school in Kokap, Kulon Progo, Yogyakarta (May-September 2013)

\begin{tabular}{lcc}
\hline \multicolumn{1}{c}{ STH infections } & $\begin{array}{c}\text { pre-treatment } \\
(\%)\end{array}$ & $\begin{array}{c}\text { 3-month- } \\
\text { post- } \\
\text { treatment } \\
(\%)\end{array}$ \\
\hline Total & 43.1 & 35.4 \\
A. lumbricoides (A. 1) & 7.1 & 8.7 \\
T. trichiura (T. t) & 64.3 & 60.9 \\
A. 1+ T. T & 21.4 & 13.0 \\
T. $\mathrm{t}+$ hookworm (Hw) & 7.1 & 8.7 \\
A. $1+$ T. $\mathrm{t}+$ Hw & 0 & 4.3 \\
\hline
\end{tabular}

Students infected with STH on pretreatment examination were treated with anthelminthic drugs by the Primary Health Center. Two weeks after treatment, the students were asked to collect the stool samples for evaluation of treatment by calculating the cure rate $(\mathrm{CR})$ and egg reduction rate (ERR). The CR and ERR were 100\% for hookworm and $A$. lumbricoides infentions treated with pyrantel pamoat while albendazol for $T$. trichiura infection gave $12.8 \% \mathrm{CR}$ and $62.4 \%$ ERR (TABLE 4). Nevertheless, the Wilcoxon test for T. trichiura in this study showed there was significant reduction egg count (EPG) before and 2 week after treatment $(\mathrm{p}<0.05)$. Perhaps, the decreasing ability to lay eggs in $T$. trichiura might be due to the declining number of adult worms after treatment.

TABLE 3. McNemar analysis for result of infection rate of soil-transmitted helminth at pre-treatment and 3 months post-treatment intervals at a primary school students in Kokap, Kulon Progo, Yogyakarta (MaySeptember 2013)

\begin{tabular}{llcccc}
\hline & & \multicolumn{2}{c}{3 months post-treatment } & \multirow{2}{*}{ Total } & $\mathrm{p}$ \\
\cline { 3 - 4 } & & Positive & Negative & & \\
\hline \multirow{2}{*}{ Pre-treatment } & Positive & 18 & 10 & 28 & \multirow{2}{*}{0.302} \\
& Negative & 5 & 32 & 37 & \\
\hline \multirow{2}{*}{ Total } & & 23 & 42 & 65 & \\
\hline
\end{tabular}

TABLE 4. The CR and the ERR of STH at 2-weeks-posttreatment at a primary school in Kokap, Kulon Progo, Yogyakarta (May-September 2013)

\begin{tabular}{lcccc}
\hline \multirow{2}{*}{ Types of STH } & Pre-treatment & 2 weeks post-treatment & & \\
\cline { 2 - 3 } & Mean (epg) & Mean (epg) & & ERR (\%) \\
\hline A. lumbricoides & $22,383.4$ & 0 & 100 & 100 \\
T. trichiura & 581.8 & 219 & 12.8 & 62.4 \\
\hline Hookworm & 792 & 0 & 100 & 100 \\
\hline
\end{tabular}

Note: epg (eggs per gram of faeces) 
The 3-months-STH infections after treatment were divided into $33.3 \%$ re-infected cases and $66.7 \%$, new cases in A. lumbricoides infection, while all of hookworm infections
$(100 \%)$ were new cases. On the other hand, $T$. trichiura infection also gave $4.8 \%$ reinfection cases, $14.3 \%$ new cases and $81 \%$ untreated cases (TABLE 5).

TABLE 5. Infection rate of types of STH at 3- months post treatment at a primary school in Kokap, Kulon Progo, Yogyakarta (May-September 2013)

\begin{tabular}{lcccccc}
\hline \multirow{2}{*}{ 3-months-posttreatment } & \multicolumn{2}{c}{ A. lumbricoides } & \multicolumn{2}{c}{ T. trichiura } & \multicolumn{2}{c}{ Hookworm } \\
\cline { 2 - 7 } & $\mathrm{n}$ & $\%$ & $\mathrm{n}$ & $\%$ & $\mathrm{n}$ & $\%$ \\
\hline Reinfected cases & 2 & 33.3 & 1 & 4.8 & 0 & 0 \\
New cases & 4 & 66.7 & 3 & 14.3 & 3 & 100 \\
Untreated cases & 0 & 0 & 17 & 81 & 0 & 0 \\
\hline Total & 6 & 100 & 21 & 100 & 3 & 100 \\
\hline
\end{tabular}

Some variables in this research were analyzed using Chi Square test to determine the incidence of infection within 3 months after treatment. Independent variables being analyzed were previous infection characteristics, personal hygiene, and water supply/ sanitation.

According to TABLE 6, it could be seen that all subjects who were suffering from multiple infection, 8 cases, also tested positive 3 months after treatment. Ten of 20 subjects with single previous infection (50\%) still tested positive 3 months after treatment. The result of Chi-square test for this variable were $p<0.05$ which means that there are statistically significant correlation between the number of species in previous STH infection with the prevalence of STH infection 3 months after treatment. Odds ratio (OR) were 2.00 which means that the prescence of more than 1 types of previous STH infection has 2 times more risk of recurent STH infection 3 months after treatment.

TABLE 6. Bivariate analysis of previous infection characteristics (pretreatment) and prevalence of STH infection 3 months after treatment at primary school students in Kokap, Kulon Progo, Yogyakarta (May-September 2013) ( $\mathrm{n}=28)$

\begin{tabular}{|c|c|c|c|c|c|c|c|c|c|c|}
\hline & \multirow{2}{*}{ Variable } & \multicolumn{2}{|c|}{ positive } & \multicolumn{2}{|c|}{ negative } & \multicolumn{2}{|c|}{ Total } & \multirow{2}{*}{$\mathrm{p}$} & \multirow{2}{*}{ OR } & \multirow{2}{*}{$95 \% \mathrm{CI}$} \\
\hline & & $\mathrm{N}$ & $\%$ & $\mathrm{~N}$ & $\%$ & $\mathrm{~N}$ & $\%$ & & & \\
\hline \multirow{2}{*}{$\begin{array}{l}\text { Previous STH } \\
\text { infection }\end{array}$} & multiple & 8 & 100 & 0 & 0 & 8 & 100 & \multirow{2}{*}{0.025} & \multirow{2}{*}{2.00} & \multirow{2}{*}{$1.30-3.10$} \\
\hline & single & 10 & 50 & 10 & 50 & 20 & 100 & & & \\
\hline Total & & 18 & & 10 & & 28 & & & & \\
\hline
\end{tabular}


Rochmah et al., Infection, cure and egg reduction rates of soil-transmitted helminth infections after anthelminthic drugs treatment among school children in Kokap, Yogyakarta, Indonesia

TABLE 7. Bivariate analysis of personal hygiene and prevalence of STH infection 3 months after treatment at primary school students in Kokap, Kulon Progo, Yogyakarta (May-September 2013)

\begin{tabular}{|c|c|c|c|c|c|c|c|c|c|c|}
\hline \multirow{2}{*}{$\begin{array}{l}\text { Variable } \\
\mathrm{n}\end{array}$} & & \multicolumn{2}{|c|}{ Positive } & \multicolumn{2}{|c|}{ negative } & \multicolumn{2}{|c|}{ Total } & \multirow[b]{2}{*}{$\mathrm{p}$} & \multirow{2}{*}{ OR } & \multirow{2}{*}{$95 \% \mathrm{CI}$} \\
\hline & & $\%$ & $\mathrm{n}$ & $\%$ & $\mathrm{n}$ & $\%$ & & & & \\
\hline \multirow{3}{*}{$\begin{array}{l}\text { Hand washing } \\
\text { before eating }\end{array}$} & No & 2 & 50 & 2 & 50 & 4 & 100 & 0.570 & 2.56 & $0.31-20.1$ \\
\hline & With water only & 12 & 41.4 & 17 & 58.6 & 29 & 100 & 0.277 & 1.8 & $0.62-5.25$ \\
\hline & With water and soap & 9 & 28.1 & 23 & 71.9 & 32 & 100 & 0.826 & Ref. & \\
\hline \multirow{2}{*}{ Defecation site } & ground & 0 & 0 & 2 & 100 & 2 & 100 & \multirow{2}{*}{0.536} & \multirow[b]{2}{*}{1.58} & \multirow{2}{*}{$1.31-1.90$} \\
\hline & toilet & 23 & 36.5 & 40 & 63.5 & 63 & 100 & & & \\
\hline \multirow{3}{*}{$\begin{array}{l}\text { Hand wshing } \\
\text { after toilet }\end{array}$} & No & 1 & 25 & 3 & 75 & 4 & 100 & 1.000 & 0.67 & $0.63-7.00$ \\
\hline & With water only & 8 & 42.1 & 11 & 57.9 & 19 & 100 & 0.509 & 1.46 & \multirow[t]{2}{*}{$0.48-0.43$} \\
\hline & With water and soap & 14 & 33.3 & 28 & 66.7 & 42 & 100 & 1.000 & Ref. & \\
\hline \multirow{2}{*}{$\begin{array}{l}\text { Habit of playing } \\
\text { with soil }\end{array}$} & Yes & 17 & 32.7 & 35 & 67.3 & 52 & 100 & \multirow{2}{*}{0.518} & \multirow{2}{*}{0.57} & \multirow{2}{*}{$0.17-1.95$} \\
\hline & No & 6 & 46.2 & 7 & 53.8 & 13 & 100 & & & \\
\hline \multirow{3}{*}{$\begin{array}{l}\text { Hand and foot } \\
\text { washing after } \\
\text { playing }\end{array}$} & No & 4 & 40 & 6 & 60 & 10 & 100 & 0.664 & 2.00 & $0.37-11.0$ \\
\hline & With water only & 15 & 38.5 & 24 & 61.5 & 39 & 100 & 0.340 & 1.88 & \multirow[t]{2}{*}{$0.55-6.90$} \\
\hline & With water and soap & 4 & 25 & 12 & 75 & 16 & 100 & 0.604 & Ref. & \\
\hline \multirow{2}{*}{ Using footwear } & No & 6 & 31.6 & 13 & 68.3 & 19 & 100 & \multirow{2}{*}{0.680} & \multirow{2}{*}{0.79} & \multirow{2}{*}{$0.25-2.46$} \\
\hline & Yes & 17 & 37 & 29 & 63 & 46 & 100 & & & \\
\hline \multirow{2}{*}{$\begin{array}{l}\text { Habit of biting } \\
\text { nails }\end{array}$} & No & 3 & 25 & 9 & 75 & 12 & 100 & \multirow{2}{*}{0.515} & \multirow{2}{*}{0.55} & \multirow{2}{*}{$0.13-2.28$} \\
\hline & Yes & 20 & 37.7 & 33 & 62.3 & 53 & 100 & & & \\
\hline \multirow{2}{*}{$\begin{array}{l}\text { Habit of cutting } \\
\text { nails }\end{array}$} & $>$ once weeks & 8 & 47.1 & 9 & 57.9 & 17 & 100 & \multirow{2}{*}{0.241} & \multirow{2}{*}{1.96} & \multirow{2}{*}{$0.63-6.06$} \\
\hline & Once week & 15 & 31.3 & 33 & 68.8 & 48 & 100 & & & \\
\hline Nails condition & Dirty & 13 & 41.9 & 18 & 58.1 & 31 & 100 & & & \\
\hline & Clean & 10 & 29.4 & 24 & 70.6 & 34 & 100 & 0.292 & 1.13 & $0.62-4.84$ \\
\hline Total & & 23 & & 42 & & 65 & & & & \\
\hline
\end{tabular}

TABLE 8. Bivariate analysis of water supply, sanitation and prevalence of STH infection 3 months after treatment at primary school students in Kokap, Kulon Progo, Yogyakarta (May-September 2013)

\begin{tabular}{|c|c|c|c|c|c|c|c|c|c|c|}
\hline \multirow{2}{*}{ Variabel } & \multirow{2}{*}{ Kategori } & \multicolumn{2}{|c|}{ Positif } & \multicolumn{2}{|c|}{ Negatif } & \multicolumn{2}{|c|}{ Total } & \multirow{2}{*}{$\mathrm{p}$} & \multirow{2}{*}{ OR } & \multirow{2}{*}{$95 \% \mathrm{CI}$} \\
\hline & & $\mathrm{n}$ & $\%$ & $\mathrm{n}$ & $\%$ & $\mathrm{n}$ & $\%$ & & & \\
\hline \multirow{2}{*}{$\begin{array}{l}\text { Source of drinking } \\
\text { water }\end{array}$} & River & 7 & 29.2 & 17 & 70.8 & 24 & 100 & \multirow{2}{*}{0.422} & \multirow{2}{*}{0.64} & \multirow{2}{*}{$0.29-1.90$} \\
\hline & Well & 16 & 39 & 25 & 61 & 41 & 100 & & & \\
\hline \multirow{2}{*}{ Types of floor } & Ground & 14 & 43.8 & 18 & 56.3 & 32 & 100 & \multirow{2}{*}{0.165} & \multirow{2}{*}{2.07} & \multirow{2}{*}{$0.74-5.85$} \\
\hline & Cerami & 9 & 27.3 & 24 & 72.7 & 33 & 100 & & & \\
\hline \multirow{2}{*}{ Toilet in house } & No & 0 & 0 & 2 & 100 & 2 & 100 & \multirow{2}{*}{0.536} & \multirow{2}{*}{1.58} & \multirow{2}{*}{$1.3-1.9$} \\
\hline & Yes & 23 & 36.5 & 40 & 63.5 & 63 & 100 & & & \\
\hline Total & & 23 & & 42 & & 65 & & & & \\
\hline
\end{tabular}


According to bivariate analysis personal hygiene and water supply and sanitation factors being studied in this research had $\mathrm{p}>$ 0.05 (TABLE 7 and 8).

\section{DISCUSSION}

The overall infection rate observed in this study was higher than another study conducted in a primary school in Jakarta $(11.5 \%)$, an urban area in Indonesia. ${ }^{12}$ The result showed the infection rate after treatment (35.4\%) failed to achieve the expected goals less than $20 \%$ in 2015. Single infection of $T$. trichiura was the predominant group detected in the target population. The kinds of parasites found are not always homogeneous and varied according to geographical locations. ${ }^{13}$ The solid clay soil predominant in Kokap area was a suitable factor for the development of life cycles of soil-transmitted helminth particulary $A$. lumbricoides and $T$. trichiura while hookworms prefer sandy soil for the aeration larval development. ${ }^{14}$ The warm climate in this area was also a supporting factor in the development of STH, especially for embryonation of STH eggs. ${ }^{15}$

The decrease of infection rate after antihelmintic treatment showed no significantly different result. The control program of STH conducted on primary students of SDN Gunung Agung to reduce the number of STH infected students is not yet practical. The results were different from previous study on early school students, Paseban Pagi Jakarta which showed a significant decrease in infection rates $(p<0.05)$ at 6 months after treatment. ${ }^{12}$ This observed difference might be due to the function of health education in addition to the anthelminthic treatment. Soil-transmitted helminth treatment for eradication programmes followed by a longterm programmes of health education related to personal hygiene and environmental sanitation are needed in endemic areas. ${ }^{16}$

The new infection and re-infection showed that the transmission of STH infections was still present in the environment or neighborhood of the Kokap primary school children. This situation is similar to what has been reported in the aboriginal school children in Malaysia. ${ }^{3}$ Although the treatment of hookworm and $A$. lumbricoides infections was effective, source of infection and the inappropriate behavior might maintain transmission chain. In $T$. trichiura infection, untreated cases can also be a source of infection for both the individual and for others in the vicinity.

The results of this study indicate that single dose of pyrantel pamoate $10 \mathrm{mg} /$ $\mathrm{kg}$ body weigth was effective in treating $A$. lumbricoides and hookworm infections, while single dose of albendazole $400 \mathrm{mg}$ had a low efficacy to treat $T$. trichiura infections in this area. Similar results have been observed in previous studies where $\mathrm{CR}$ albendazole treatment for T. trichiura infection of 10-77\% and CR pyrantel pamoat for A. lumbricoides and hookworm infection of $38-88 \%$ and $81-$ $100 \%$, respectively. ${ }^{17}$ The results in this study were higher than previous studies which showed ERR of albendazole for T. trichiura infection only by $24.8 \% .^{18}$ Compare to other STH, T. trichiura infection was more difficult to treat ${ }^{19}$ although with light intensity particularly in endemic countries with high incidence of reinfection. ${ }^{20}$ Perhaps, the part of its body that strongly embedded in the intestinal lumen wall is contributed to this situation. ${ }^{21}$

Currently there is not a drug that has a high effectiveness for $T$. trichiura with a single dose, but there are several other studies that show a repetition of two or three doses of albendazole proved to be more effective than a single dose. ${ }^{22,23}$ Either a single dose 
treatment of albendazole or mebendazole that was given every 3 months will provide a better effect in reducing the prevalence and intensity of STH infections in children. ${ }^{13}$ The World Health Organization recommends periodic drug treatment (deworming) to all children living in endemic areas with once a year when prevalence of STH infections in the community is over $20 \%$ and twice a year when the prevalence of STH infections in the community is over $50 \%{ }^{24}$

All children who were suffering from more than one type of STH infection before treatment, still tested positive 3 months after treatment. Chi-square analysis showed $p$ value $<0.05$, which means that there was statistically significant correlation between the amount of previous STH infection with the occurrence of STH infection 3 months after treatment for primary students of SDN Gunung Agung, Kokap. Odds Ratio were 2 , which means that subjects who had more than 1 types of previous STH infection had 2 times more risk of reccurent STH infection 3 months after treatment. This results showed that children who suffered from more than one type of previous STH infection, has more risk factor, hence they are more prone to reccurent infections even after treatment.

This research assessed water supply and sanitation through 3 variables i.e. daily source of water, types of housing tiles, and the availabilityoflavatory/toilet.Mostrespondents used water from well as daily source of water, eventhough some still use water from springs and rivers. Chi-square analysis showed $\mathrm{p}$ value $>0.05$, which means that there were no statistically significant correlation between water source and the occurence of STH 3 months after treatment. This result was in line with a research reported by Damanik ${ }^{25}$, but different with that reported by Alemu et al. ${ }^{26}$ which showed that source of water correlated with STH infection incident. Although clean water source was available, inadequate water supply during the study period might affect the correlation. This study also found no statistically significant correlation between lavatory/toilet availability with the occurence of STH infection after treatment. Having no own lavatory at home did not mean that children were STH infected. Perhaps, utilization of lavatory might contribute more to STH infection rather just the ownership. Another study at school children in Mataram, Nusa Tenggara Barat, Indonesia also showed no statistically significant correlation between environmental sanitation with the prevalence and intensity of STH infection ${ }^{27}$ which might be influenced by the existence of intensive health promotion.

No correlation between personal hygiene, environmental sanitation and STH might be influenced by some factors that could not covered in this study e.g. personal hygiene of other age groups. Toddler and adults that did not included in this study might contribute a factor that cause persisting source of infection in this school children environment particularly when open defecation is still a common practice. Another factor that need to be explored is possibility of contaminated soil around housing areas by STH eggs as source of persistence infection. ${ }^{28}$

\section{CONCLUSIONS}

Anthelmintic treatment is effective on hookworm and A. lumbricoides infections, shown by CR and ERR but not for T. trichiura infection. Re-infection and treatment failure detected after 3 month treatment at the schoolchildren of SDN Gunung Agung, Kokap and low effectiveness of treatment against $T$. trichiura infection demands consideration of alternative treatment approaches. Periodic 
treatment in this area is necessary to interupt the transmission of STH.

\section{ACKNOWLEDGEMENTS}

The authors wish to thank all subjects who willingly participated in this study, the Headmaster and Teachers of SDN Gunung Agung and the Head of Primary Health Center Kokap I, Kulon Progo, Yogyakarta for all support and cooperation during this research.

\section{REFERENCES}

1. Hotez PJ, Molyneux DH, Fenwick A, Kumaresan J, Sachs SE, Sachs JD, et al. Control of negleted tropical disease. $\mathrm{N}$ Engl J Med 2007; 357: 1018-27. https://doi.org/10.1056/NEJMra064142

2. Depkes RI. Keputusan Menteri Kesehatan mengenai Pedoman Pengendalian Cacingan. 2006. [cited 2012, August3]: Available from URL: http://www.depkes.go.id/downloads/ Kepmenkes/KecacingandanFilariasis/

3. Norhayati M, Oothuman P, Azizi O, Fatmah MS. Efficacy of single dose albendazole on the prevalence and intensity of infection of soiltransmitted helminths in Orang Asli children in Malaysia. Southeast Asian J Trop Med Pub Health 1997; 28:563-9.

4. Luoba AI, Wenzel GP, Estambale B, Ouma $\mathrm{JH}$, Alusala D, Ayah R, et al. Earth-eating and reinfection with intestinal helminths among pregnant and lactating women in Western Kenya. Trop Med Int Health 2005; 10: 220-7. https://doi.org/10.1111/j.13653156.2004.01380.x

5. Al-Mekhlafi MH, Surin J, Atiya AS, Mahdy AKM, Abdullah HC. Pattern and predictors of soil-transmitted helminth reinfections among Aboriginal school children in rural Peninsular Malaysia. Acta Tropica 2008; 107: 200-4. ht tps://doi.org/10.1016/j . actatropica.2008.05.022

6. Vandemark LM, Jia TW, Zhou ZN. Social science implications for control of helminth infections in Southest Asia. Adv Parasitol 2010; 73: 137-70. https://doi.org/10.1016/S0065308X(10)73006-2

7. Hoa NTV, Noda S, Uga S, Thuan LK, Aoki Y, Fujimaki Y. Parasite egg contamination of hands in a sub urban area of Hanoi, Vietnam. Trop Med Health 2010; 38 (2): 75-9. https://doi.org/10.2149/tmh.2010-02

8. Puskesmas Kokap I. Profil Puskesmas Kokap I Kecamatan Kokap. Yogyakarta: Kabupaten Kulon Progo, 2009.

9. Puskesmas Kokap I. Profil Puskesmas Kokap I Kecamatan Kokap. Yogyakarta: Kabupaten Kulon Progo, 2011.

10. WHO. Basic laboratory methods in medical parasitology 1991. ([cited 2015 December 16]. Available from: http://apps.who.int/iris/ bitstream/10665/40793/1/9241544104 (part1).pdf

11. Depkes RI. Pedoman Pengobatan dasar di Puskesmas 2007. Jakarta: Direktorat Jenderal Kefarmasian, 2007.

12. Winita R, Mulyati, Astuty H. Upaya pemberantasan kecacingan di Sekolah Dasar. Makara Kesehatan 2012; 16: 2.

13. Nkengazong L, Njiokou F, Wanji S, Teukeng F, Enyong $\mathrm{P}$, Asonganyi $\mathrm{T}$. Prevalence of soil-transmited helminths and impact of albendazol on parasitic indices in Kotto Barombi and Marumba II Village (South-West Cameroon). African J Environ Sci Technol 2010; 4(3) : 115-21. https://doi.org/10.5897/AJEST09.205

14. Mabaso MLH, Appleton CC, Hughes JC, Gouws E. The effect of soil type and climate on hookworm (Necator americanus) distribution in Kwa Zulu-Natal, South Africa. Trop Med Int Health 2003; 8:722-7. https://doi.org/10.1046/j.13653156.2003.01086.x

15. Jia T, Melville S., Utzinger J, King CH, Zhou $\mathrm{X}$. Soil-transmitted helminth reinfection after drug treatment : a systematic review and metaanalysis. PloS Negl Trop Dis 2012; 6(5): e1621. https://doi.org/10.1371/journal.pntd.0001621 
Rochmah et al., Infection, cure and egg reduction rates of soil-transmitted helminth infections after anthelminthic drugs treatment among school children in Kokap, Yogyakarta, Indonesia

16. Norhayati M, Oothuman $\mathrm{P}$, Fatmah MS, Minudin YM, Zainuddin B. Hookworm infection and reinfection following treatment among Orang Asli children. Med J Malaysia 1995; 50(4): 314-9.

17. Vercruysse J, Albonico M, Behnke J, Coles G, Churcher T, Drake L, et al. Monitoring anthelminthic for soil-transmitted helminths (STH). Working Group on STH. 2008. [cite 2013, April15]. Available from URL: www. who.int/neglegted_disease/_preventive chemotherapy/chemoterapy_anthelminthic drug.WHO_WB_final.pdf.

18. Saathoff E, Olsen A, Kvalsvig JD, Appleton CC. Pattern of geohelminth infection, impact of albendazol treatment and re-infection after treatment in schoolchildren from rural KwaZulu-Natal/ South-africa. BMC Infect Dis 2004; 4:27. DOI: 10.1186/1471-2334-4-27 https://doi.org/10.1186/1471-2334-4-27

19. Ranque S, Chippaux JP, Garcia A, Boussinessq M. Follow-up of Ascaris lumbricoides and Trichuris trichiura infections in children living in a community treated with ivermectin at 3 monthly interval. Ann Trop Med Parasitol 2001; 95(4): 389-93. https://doi.org/10.1080/00034980120065822 https://doi.org/10.1080/00034983.2001.11813 651

20. Grossman L.B. Infection control in the child care center and preschool 8th ed 2012; 309310. [cited 2014, September 20]. Available from URL: www.demosmedpub.com

21. Nasr NA, Al-Mekhlafi HM, Ahmed A, Roslan MA, Bulgiba A. Toward an effective control programme of soil-transmitted helminth infections among Orang Asli in rural Malaysia. Part 1: prevalence and associated key factors. Parasites and Vectors 2013; 6:27. DOI: 10.1186/1756-3305-6-28 https://doi.org/10.1186/1756-3305-6-28
22. Horton J. Albendazol : A review of anthelminthic efficacy and safety in humans. Parasitology 2000; 121:13-32. https://doi.org/10.1017/S0031182000007290

23. Olsen A, Nawirl J, Friss H. The impact of iron supplementation on reinfection with intestinal helminth and Schistosoma mansoni in western Kenya. Trans R Soc Trop Med Hyg 2000; 94: 493-9. https://doi.org/10.1016/S00359203(00)90063-4

24. WHO. Deworming to combat the health and nutritional impact of soil-transmitted helminth. E-library of Evidence for Nutrition Actions (eLENA), 2012. [cited 20014 September 20] Available from URL: http://www.who.int/ elena/titles/ bbc/deworming/en/

25. Damanik DM. Sanitasi rumah, sekolah, personal hygiene dan infeksi soil-transmitted helminth (STH) pada murid sekolah dasar di Pulau Palue, Provinsi Nusa Tenggara Timur. [Thesis]. Yogyakarta, Ilmu Kesehatan Masyarakt, Fakultas Kedokteran UGM; 2012.

26. Alemu A, Atnafu A, Addis Z, Shiferaw Y, Teklu T, Mathewos B, et al. Soil-transmitted helminths and Schistosoma mansoni Infections among School Children in Zarima town, Northwest Ethiopia. BMC Infect Dis 2011; 11:189. DOI: $10.1186 / 1471-2334-11-189$ https://doi.org/10.1186/1471-2334-11-189

27. Hidayat $T$. Kesehatan lingkungan, higiene perorangan dan intensitas penyakit kecacingan dengan status gizi pada anak SD di Kota Mataram. [Thesis]. Yogyakarta; Sekolah Pascasarjana Universitas Gadjah Mada, 2002.

28. Wardhiana S. Peranan ibu rumah tangga dalam meningkatkan kesehatan lingkungan sebagai upaya memutus rantai penularan penyakit cacing pada anak Sekolah Dasar. [Thesis]. Yogyakarta: Sekolah Pscasarjana Universitas Gadjah Mada, 1997. 